原

\title{
胆石症に対する術前 PTCの意義
}

\author{
聖園病院外科 \\ 奈良井 省 吾 大塚 為 和 \\ 同内科 \\ 今泉信作栗林和敏佐藤利 \\ 佐 藤 康 行
}

\section{SIGNIFICANCE OF PREOPERATIVE PERCUTANEOUS TRANSHEPATIC CHOLANGIOGRAPHY FOR CHOLELITHIASIS}

Seigo NARAI and Tamekazu OTSUKA

Department of Surgery, Misono Hospital, Niigata

Shinsaku IMAIZUMI, Kazutoshi KURIBAYASHI

Takeshi SATO and Yasuyuki SATO

Department of Internal Medicine, Misono Hospital, Niigata

遺残結石防止と結石の胆妻から総胆管への落下や総胆管から十二指腸への排出の頻度 を知る目的で, US, DIC, それに ERCで胆石症と診断された45症例に対して開腹する 2 〜 3 時間前にPTCを行なった. その結果， 6 症例 (13.3\%) はPTC 後術前診断を訂正 した。すなわち，総胆管内結石の消失していた症例が 2 例，胆重と総胆管内結石の消失 症例が 1 例，総胆管内結石の発見された症例が 3 例であった。これら6 症例中 4 例は ERCから PTCまでの間に腹痛が出現していた。

以上の結果より，胆石症と診断されてから手術までの期間が長い時や，腹痛が出現し た場合には結石の落下や自然排出があり得るので, 手術前に胆道を直接造影法で再精查 することが望ましいと思われた，そのためPTCは有用である。正確な術前診断は遗残結 石防止と不必要な総胆管切開術を避けらることにつながるすのと考えている.

索引用語：胆石症, 経皮経肝胆管造影法

\section{はじめに}

胆石症手術後の遺残結石は術前検查法が進歩し, 術 中胆道造影法が一般化された現在においても，その頻 度は 1 〜 $6 \%$ と報告されている1)-5).

衍中胆道造影を行なっても見逃される総胆管内遺残 結石の多くは総胆管末端の小結石であり，かかる結石 の存在を㭪前に超音波検査法(US), 点滴静注胆貫胆管 造影法 (DIC) で確診することはかなり困難である677). 従って, 内視鏡的胆管造影法 (ERC) P経皮経肝胆管 造影法 (PTC) で胆道を直接造影し, 病変部位を的確 にとらえることが遺残結石防止のためには極めて大切 である.

一般的に, 胆石症の場合は胆石症と診断が下されて
から，直ちに手術することは比較的少ない。はたして， 手術を待つ間に胆重から総胆管への結石の落下や総胆 管から十二指腸への結石の自然排出が起こり得ないで あろらか。すし，起こり得るとすれば，正しい術前診 断を得ないままに手術を受ける症例が存在することに なる。

遺残結石防止と結石の落下や自然排出の頻度を知る 目的で，US, DIC，それに ERCで胆石症と診断された 症例に対し, 手術直前にPTCを施行し, 興味ある成績 を得たので報告する。

\section{对象}

US, DIC, ERC で胆石症と診断した45症例に対し て, 開腹する $2 \sim 3$ 時間前にPTCを施行した. PTC 
は高田の方法" ${ }^{8}$ 従って, 23G の穿刺針を使用し，4回 を限度と定め穿刺した。なお，超音波誘導下に胆重を 穿刺した症例は今回の対象から除外した。,US, DICは 全症例に，ERCは30例に行なわれていた。造影霍とし てPTCには $30 \%$ の，ERCには60\%のウロクラフィン を用いた，開腹すると直ちにPTCの訮への穿刺孔に ついて確認するととるに出血量をガーぜを用いた重量 法で測定した．45症例の疾患別内訳は，胆毫結石症 24 例, 胆衰·総胆管結石症16例，総胆管結石症 5 例であ。 た，男性16例，女性29例であり，年龄は31歳から84葴 に及んでいた。

\section{I）穿刺成功事}

結石の存在部位別穿刺成功率は胆䔄結石症24例中12 例 $(50 \%)$ ，胆衰・総胆管結石症16例中12例 (75\%)， 総胆管結石症 5 例中 5 例（100\%）であった（表 1$)$.

\section{II) 穿刺回数}

結石の存在部位別穿刺回数を表 2 に示す，胆衰結石 症では 1 回の穿刺で造影に成功することは少なく，一 方, 総胆管内に結石が存在する場合は胆管の払張を伴 らことが多いために 1 回の穿刺で造影できる割合が高 くなっている. 4 回目の穿刺でようやく造影できた症 例が 8 例あることは，穿刺回数を增やせば穿刺成功率 が高かまることを示唆している。

\section{III） PTC 後診断を訂正した症例}

PTCを行なったことで6例（13.3\%）は手術直前に 術前診断を訂正した(表 3 ). 症例 1 と 5 は総胆管内の，

\section{表 1 結石の存在部位別搴刺成䋨}

\begin{tabular}{|c|c|c|c|}
\hline 部位 & 症例 数 & 成功 例 & 成 功率 \\
\hline 善 & 24 & 12 & $50 \%$ \\
\hline 胆垔 - 総胆管 & 16 & 12 & $75 \%$ \\
\hline 総 阳 管 & 5 & 5 & $100 \%$ \\
\hline 計 & 45 & 29 & $64 \%$ \\
\hline
\end{tabular}

表 2 結石の存在部位別穿刺回数

\begin{tabular}{|c|c|c|c|c|c|}
\hline 回 & \multicolumn{4}{|c|}{ 穿刺成功例 } & 失 䭛 例 \\
\hline 位 & I & II & III & v & VI \\
\hline 胆 & 1 & 5 & 2 & 4 & 12 \\
\hline 胆䔶・総胆管 & 5 & 3 & 0 & 4 & 4 \\
\hline 総 胆 管 & 4 & 1 & 0 & 0 & 0 \\
\hline 計 & 10 & 9 & 2 & 8 & 16 \\
\hline
\end{tabular}

表 3 PTC 後䧐断を行正した症田

\begin{tabular}{|c|c|c|c|c|c|}
\hline 应例 & 年齢 & 性別 & $\begin{array}{c}\text { PTC前 } \\
\text { 検㚗 }\end{array}$ & PTC 前診断 & PTC 後晾断 \\
\hline 1 & 73 & 男 & $\begin{array}{l}\text { DIC } \\
\text { ERC } \\
\text { UC }\end{array}$ & 総胆管結石症 & 結石な \\
\hline 2 & 64 & 女 & $\begin{array}{l}\text { DIC } \\
\text { US }\end{array}$ & 胆筑結石应 & 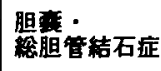 \\
\hline 3 & 33 & 女 & $\begin{array}{c}\text { DIC } \\
\text { ERC } \\
\text { US }\end{array}$ & 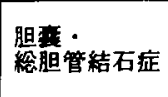 & 結石なし \\
\hline 4 & 51 & 女 & $\begin{array}{l}\text { DIC } \\
\text { US }\end{array}$ & 胆結石症 & 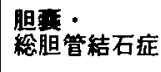 \\
\hline 5 & 43 & 女 & $\begin{array}{l}\text { DIC } \\
\text { ERC } \\
\text { US }\end{array}$ & 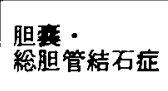 & 胆貫結石症 \\
\hline 6 & 63 & 女 & $\begin{array}{c}\text { DIC } \\
\text { ERC } \\
\text { US }\end{array}$ & 腿妻結石症 & 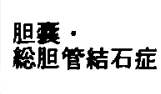 \\
\hline
\end{tabular}

症例 3 は胆重と総胆管内の結石が消失していた。症例 $2 ， 4 ， 6$ は総胆管内に結石の存在することが明らか となった．次に症例の概略を示す。

症例 1 は73歳の男性で黄疸, 発熱, 上腹部痛を主訴 として入院. US では胆票内に結石が見られたが，5日 後の ERCでは総胆管内のみに 1 個の結石像を認め た。ところが，ERC 後20日目に行なったPTCでは総 胆管内にも結石を認めることはできなかった（写真 1). 本症例は ERC 後 4 日目に右乎肋部に疝痛が出現 しており，その際に総胆管内の結石は十二指腸に排出 されたるのと考えられた。

症例 2 は64葴の女性でUS と DICでは総胆管の扗 張や総胆管内結石は見られず，胆菱結石症と診断して いた.しかし， 5 カ月後の手術当日にPTCを行なった ところ総胆管の拡張は認められないすのの, 総胆管内 に存在する 2 個の小結石が明らかとなった。本症例㤌 US, DIC 施行時すでに総胆管内に結石が存在したが描 出できなかったのか，あるいはUSと DIC 施行後に胆 莗から総胆管内に結石が落下したのかは明らかでな い.

症例 3 は33歳の女性で, US と DICで胆重内と総胆 管内に存在する大少多数の結石が明らかとなり，ERC でる同様の所見が得られた(写真 2).ところが，ERC 後33日目の手術当日にPTCを行なったところ全ての 結石は消失しており，総胆管の扗張も認められなかっ 


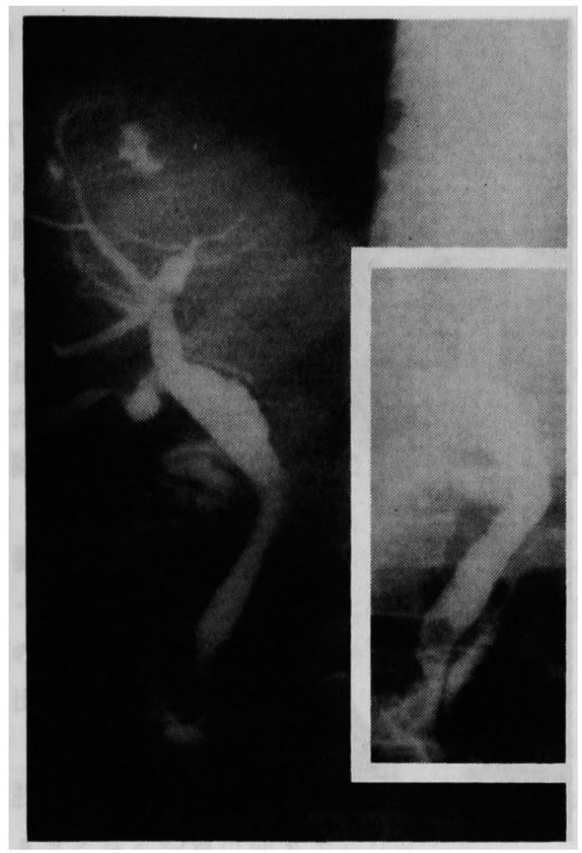

写真 1 症例 1 の ERC（玝内）と PTC

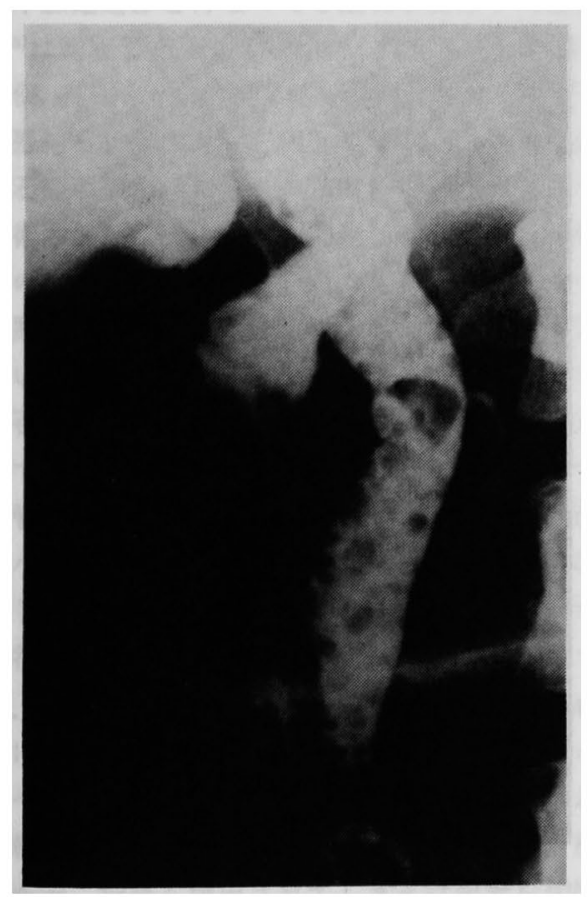

写真 2 症例 3 の ERC

た(写真 3).手術を中止し，9カ月後にDICを行なっ たが結石は見られなかった，本症例は ERCから PTC 施行までの間に何の自覚症状も有していなかった。

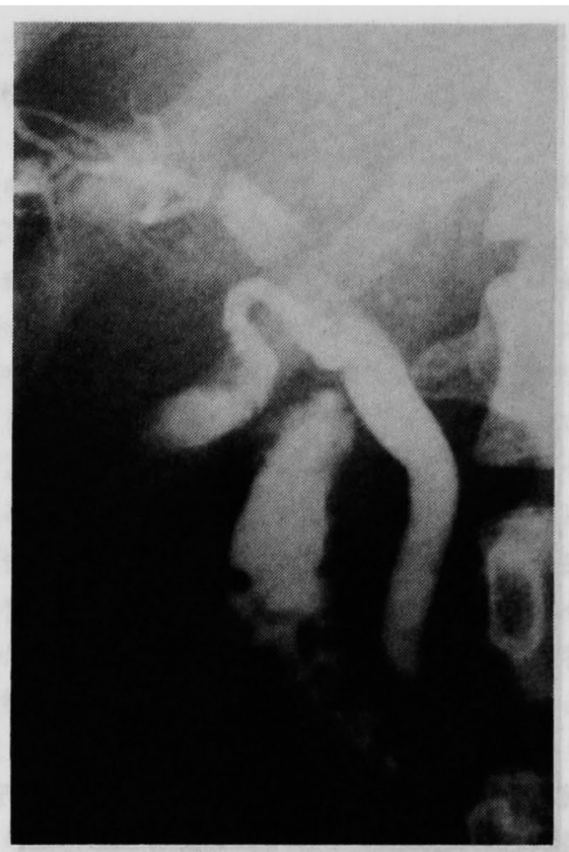

写真 3 症例 3 の PTC

症例 4 は51歳の女性で，US, DIC で胆咅結石症と診 断していたか，手術当日の早朝より右季肋部に疝痛が 出現した，直ちにPTCを行なったところ総胆管末端 に結石の嵌頓している所見が得られた。本症例は手術 当日に胆衰より総胆管内に結石が落下したすのと考え られた。

症例 5 は43歳の女性で，US と DIC で胆衰内結石と 総胆管の抬張が認められ，ERCで総胆管内結石が明ら かとなった（写真 4 ).ところが, ERC 後 6 日目に PTC を行なったところ,総胆管の払張は認められるすのの， 結石像は見られなかった（写基 5)。本症例は ERC 後 3 日間持続する鈍痛を右季助部に自覚していた。

症例 6 は63歳の女性で US では胆弯内に結石が見ら れ，DICでは胆歎は造影されず，また，総胆管には桩 張もなく結石も見られなかった. ERCです総胆管内に 結石像を認めなかった(写真 6)，ところが，ERC 後26 日目の手術当日にPTCを行なったところ，総胆管の 拻張は認められないものの, 総胆管内に存在する 1 個 の小結石が描出された (写真 7). 本症例は ERC 後 4 日目と7日目に腹痛が出現しており，その時に胆言よ り総胆管内に結石が落下したすのと考えられた。

IV）PTCの所見と術中胆道造影所見との比較

PTCを行ない造影に成功した29例において，PTC の所見と $30 \%$ のウクラランンを用いた術中胆道造影 


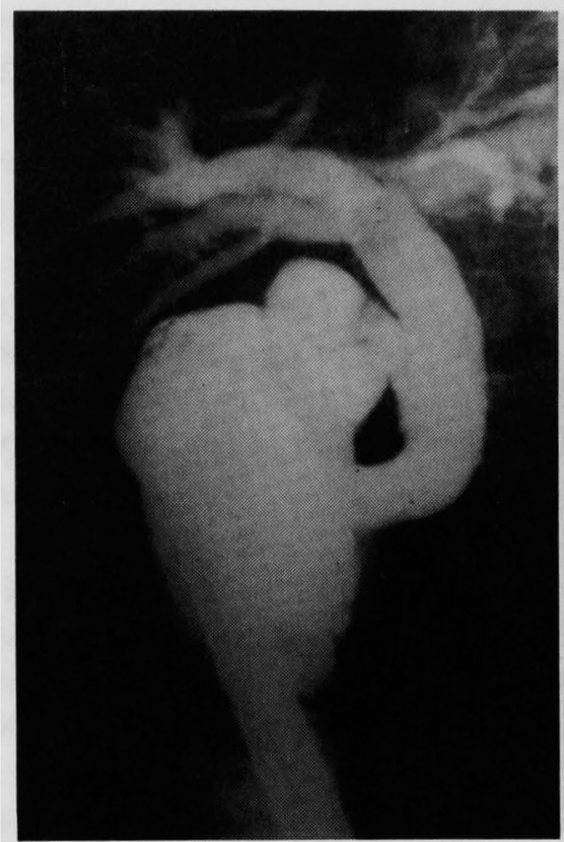

写真 4 症例 5 の ERC：この写真では総肝管に結石 が存在する

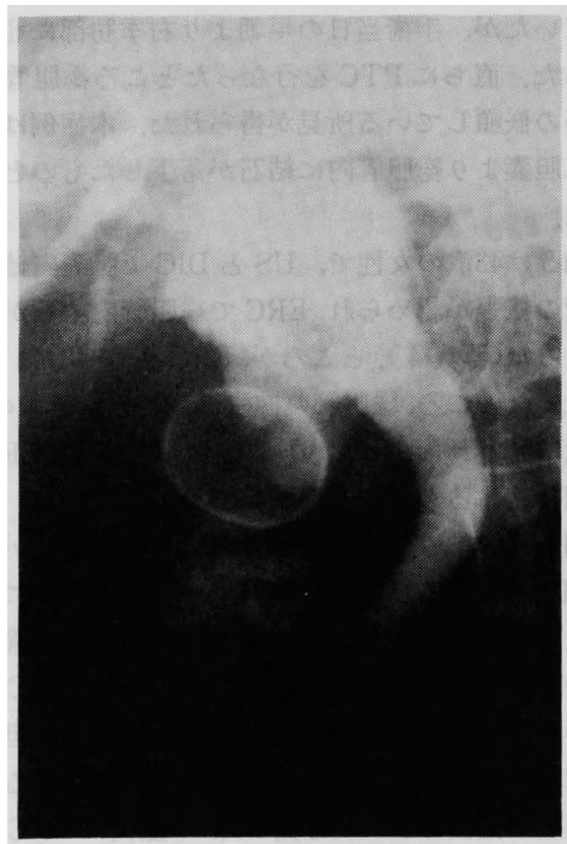

写真 5 症例 5 の PTC

所見とを比較したところ，両者の所見が不一致であっ たのは 1 例のみであった。 その 1 例は, PTCでは総胆 管内に 2 個の小結石が認められていたが, 術中胆道造

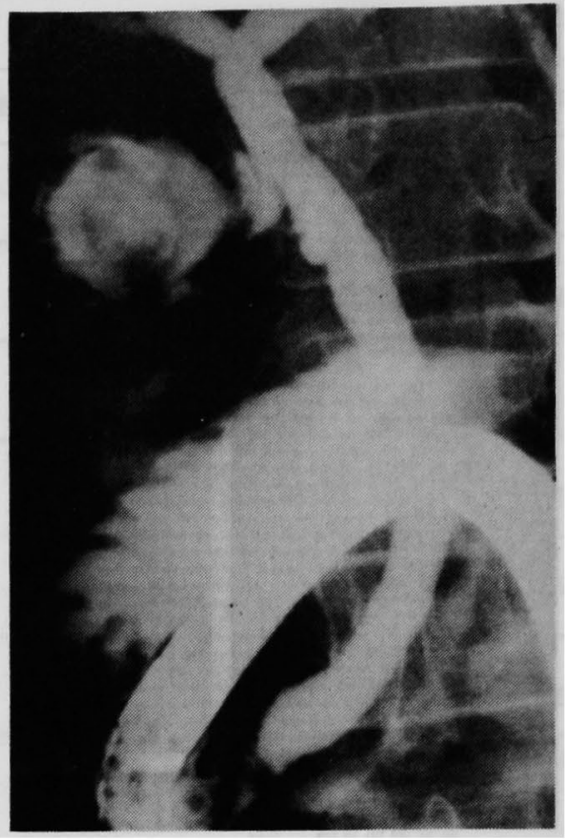

写事 6 症例 6 の ERC

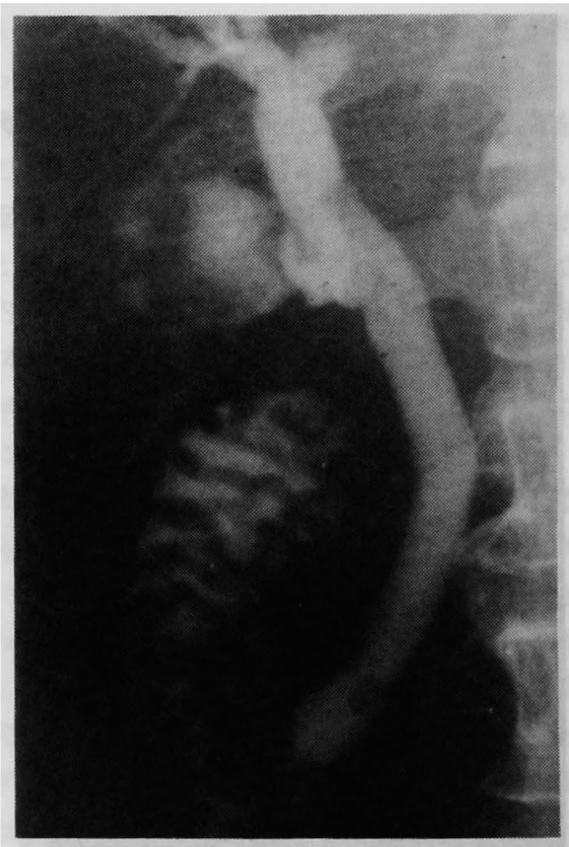

写基 7 症例 6 の PTC

影では 1 個しか確認できなかった64歳の女性症例で あった。恐らく，術中操作中に 1 個の結石は総胆管か ら十二指腸に非出されたものと考えられた。 


\section{V) 合併症}

\section{a）腹腔内出血}

PTCによる腹腔内出血は痕跡程度の症例がはとん どであったが, $30 \mathrm{~g}$ から50g の出血を 3 例に, $50 \mathrm{~g}$ 以上 の出血を 4 例に認めた。 $50 \mathrm{~g}$ 以上出血していた 4 例中 2 例は呼吸停止が困難な症例であり，肝表面に約 $1 \mathrm{~cm}$ の亀裂が生じていた，最す大量に出血していたのは高 血王症を有する80歳の高齢者で 2 回穿刺したたけで あったが，約 $250 \mathrm{~g}$ の出血が喼められた。しかし； 1 症 例を除くいずれすが開腹時すでに止血されていれ。

b) 胆道出血

胆咅摘出後, 術中胆道造影のために胆垔管よりカ ニューレを総胆管内に覒入した際に吸引された胆汁に 血液の混じていた症例が 2 例あった。しかし， 2 症例 とも出血量はわずかであった。

c）その他

腹腔内人の胆汁漏出は見られなかった。また，気胸 やショックなとの合併症も生じなかった。

\section{考案}

術中胆道造影を行なっても結石を見逃した症例を高 橋 ${ }^{3)}$ は総胆管結石症370例中 4 例, 肝内結石症 114 例 中 6 例, 友田 () $^{4}$ 総胆管結石症242例中 8 例, 下山ら5) は遺残結石16例中 6 例と報告している。術中胆道造影 は胆石症手術の際にはルチンに行ならべきるのである が，術中といら条件下にあるため種々の制限を受け， 满足のいく情報を常に得られないところに見逃しの大 きな原因があるものと考えられる，胆道鏡が普及して きているが，胆管を切開し胆道鏡で胆管の精査を行な らか否かは胆道造影所見のいかんによって決定される ものであり，胆道造影の重要さがここにも存在する。

総胆管結石症において，見逃し遗残の多くは総胆管末 端の小結石であるが，その小結石は術前に ERC ある いはPTCで胆道を直接造影し，あらゆる角度から撮 影を行ない慎重に読璟することで発見されらるむので ある、しかし，ERCあるいはPTCを施行し，総胆管 結石はないと判断してから手術までの間に胆变から粉 胆管への結石の落下があれば，それまでに得られてい た情報は根底から覆されることになる，逆に，棇胆管 結石が十二指腸へ排出されてしまえば胆管を切開する 必要性がなくなる，亀田 ${ }^{99}$ は 3 カ月から15年とい5 長期間の観察であるが，胆竞結石症122例中 9 例 （7.4\%）に結石の自然消失を認めている。

以上の観点から，できる限り正確な術前診断を得る と同時に，結石の胆震から総胆管への落下ゃ総胆管か
ら十二指腸への排出がどの位起こり得るのかといら問 題を検討するために，手術直前にPTCを行なってみ た。

その結果，今回対象とした45例中 6 例（13.3\%）は PTC 後術前診断を訂正した。症例の概略は前述した か，総胆管結石の消失した症例か; 2 例，胆落と総胆管 結石の消失した症例か１例，総胆管結石の発見された 症例が 3 例であった。そして，この 6 例中 4 例に ERC から PTC 施行までの間に腹痛の出現を認めていた。 このよ5に，胆石の落下ゃ自然排出は手術を待つ間に む起こり得るすのと認識された。すすなわ，胆石症と の診断がついてから手術までの期間が比較的長い時 や，腹痛が出現した場合には，胆霞から総胆管への結 石の落下や自然排出があり得るので，できれば手術前 に直接胆道を造影し再精梖することが望ましいと思わ れた。そのため PTC は有用である。

PTCの所見と術中胆道造影の所見とがー致しな かった症例は 1 例のみであった。この結果は, 術中胆 道造影の有用性が強調され，術前のPTCが不要であ るかの印象を与えるるのである。しかし，すでに述べ たよらに（1) 術中胆道造影を行なっても結石の見逃し 遺残を生じたとの報告のあること,(2) 術中という条件 下においては体位変換が自由にできないなど種々の制 限を受けるため满足できる写真が常に得られるとは限 らないこと, (3) 総胆管内に小結石があると診断し手術 を行なったところ，すでに結石が自然排出されていた 場合，術中胆道造影所見のみから結石なしと断を下す ことはかなり困難であることなとにより術直前に PTCを行ない病態を十分把握しておくことは有意義 と思われる。術前のPTCの所見と術中胆道造影所見 とを比較検討することにより，結石を見逃す忈れと総 胆管内結石が自然排出されておれば不必要となる総胆 管切開術を行なら危険性は避けらるbのと考えられ る。

また，自験例には症例 3 のよ5に術前PTCによる 再精査で胆震と総胆管内の結石全てが自然に排出され ていることが判明し，手術を避け得た症例や，症例 1 のよらに術前PTCの所見からみると，本来なら手術 を行ならべきでなかった症例す認められている.この よらに術前の再精查によって結石の自然排出が確認さ れ，手術を回避できた症例が有り得たといら事実は極 めて重要であり，術前にPTCを行なら意義がここに も存在する。開腹してから結石の自然排出に気付いて も時すでに遅いのである. 
PTCには合併症 ${ }^{10)}$ が皆無ではないので, 手術直前に 全例にPTCを行ならことに抵抗を感ずる万むあろら と思われる.しかし，穿刺回数を 4 回程度と定めて慎 重にPTCを施行すれば合併症は湴とんど起きないる のと考えている。今回対象とした45例の中にPTCを 行なったために衍中，術後管理に困難をきたした症例 はなかった，手術可能な胆石症例であれば，全例に術 前PTCの適応が有ると考えているが，しかし，呼吸停 止が困難な症例や，難聴などのため意思の柾通を欠く 症例に対しては行なわない方が無難である。

PTCを行なった場合むしろ問題とすべきことは，胆 变結石症で胆管の払張がない症例の穿刺成功率が 4 回 の穿刺です50\%と低いことにある.そこで，現在では， 超音波誘導下に経皮経肝胆衰造影を行ならことにして いる，但し，胆衰頚部に結石が嵌頓していたり，胆表 が萎縮していて胆衰造影を行なっても総胆管内に造影 剤が流出しないと思われる場合には従来の方法で肝内 胆管の穿刺をる考慮することとしている。

現在当院では，胆石症に対する術前検查としてUS， DIC 後，できる限りERCを行ならこととし，更に，手 術直前には原則として全例に超音波誘導下に経皮経肝 胆暴造影を施行する方針としている。

\section{おわりに}

US, DIC,それに ERCで胆石症と診断された45症例 に対して手術直前にPTCを施行して得られた成績に
ついて述べた．今後も症例を重ね検討を続けたいと考 えている。

\section{文献}

1) Farha, G.J. and Pearson, R.N.: Transcystic duct operative cholangiography. Personal experience with 500 consecutive cases. Amer. J. Surg., $131: 228-231,1976$.

2）楒 哲夫：遗残結石雑感，臨外，35：23-25, 1980.

3）高橋 涉, 植松郁之進, 新谷史明他：胆石症再手術 と遭残結石，日消外会誌，15：544-548，1982.

4）友田信之，中山和道：遭残結石症例の検討，日消外 会誌, $15 ： 549-553,1982$.

5）下山毒俊，吉田千里，峰松知親他：遗残結石症の治 㞠経输一待後胆道内視鏡的摘出術之㭪中対策を中 心に一，日臨外，43:63-70，1982。

6）木戸長一郎，遠藤登喜子，久野信義：総胆管結石症 に対する画像診断法一超音波検查とコンピュー タ一断層撮影一，胃と腸，16：625-632，1981.

7）大野孝則，大藤正雄，土屋幸治他：胆管胆石症診断 に扣ける経静脈性ならびに経皮的胆道造影法の意 義，胃之腸，16：609-614，1981.

8）高田忠敬：四解程皮的胆管ドレナーシ，医学書院， 1978.

9）龟田治男，西川 弘，月江英一他：胆石症の内科的 治療. 外科 Mook, No. 2, 胆石症へのフブローチ (佐藤寿雄編)，p. 138-147，金原出版，1982。

10）高田忠敬：PTCの適応-X-ray controlled PTC, PTCD と US guided PTC, PTCD そついて一, 臨外, 35：1132-1140，1980. 